\title{
BANK CONCENTRATION AND NON-PERFORMING LOANS IN CENTRAL AND EASTERN EUROPEAN COUNTRIES
}

\author{
Atilla ÇIFTER \\ Istanbul Kemerburgaz University, School of Economics and Administrative Sciences, \\ Mahmutbey Dilmenler Cad., No: 2634217 Bagcilar, Turkey \\ E-mail: atilla.cifter@kemerburgaz.edu.tr
}

Received 26 November 2011; accepted 06 August 2012

\begin{abstract}
This paper examines the effect of bank concentration on the non-performing loans (NPLs) for ten Central and Eastern European (CEE) countries. The short-run effect of bank concentration is tested with the generalised method of moments system and the instrumental variable approaches, and the long-run effect is tested with the fully modified ordinary least square (FMOLS) approach. The empirical analysis shows that the bank concentration is an insignificant factor on the NPLs, either in the short or in the long-run of the panel data set. On the other hand, individual FMOLS results reveal that the bank concentration reduces the NPLs in Estonia, Latvia, and Slovakia, and increases the NPLS in Bulgaria, Croatia, Lithuania, Poland, and Slovenia in the long-run. According to this evidence, the bank concentration does not reduce the credit risk for all of the CEE countries. Therefore, bank concentration may not affect systemic stability in the CEE countries. These findings are also robust in controlling several factors, including additional control variables. As a result, the relationship between the bank concentration and the NPLs, in regards to the CEE countries, is ambiguous.
\end{abstract}

Keywords: bank concentration, non-performing loans, transitional economies, GMMsystems, instrumental variable, FMOLS.

JEL Classification: G21, G28, L16.

\section{Introduction}

Macroeconomists paid more attention to the size and overall impact of the financial institutions, specifically banks, on the recent financial crises. In an early study, Beck et al. $(2006,2007)$ firstly argued that if the banking system was more concentrated, the banking system would be more stable. This is because they found that more concentrated systems are much more protected against risk. They defined the systematic banking crisis with the ratio of nonperforming loans ${ }^{1}$. They found that greater bank concentration is associated with a lower likelihood of suffering a crisis. Chang et al. (2008) and Deltuvaite (2010) also found similar results that bank concentration increas-

\footnotetext{
${ }^{1}$ When the ratio of total non-performing loans to total banking system assets exceeds ten percent, or when the government has taken extraordinary steps, this situation is defined as a banking crisis.
} 
es the stability of the banking system and decreases nonperforming loans ${ }^{2}$. In contrast to these findings, several empirical studies have shown that there is no significant correlation between bank concentration and bank stability. Schaeck et al. (2009) tested the impact of bank concentration on the likelihood of a systematic crisis by using Panzar and Rosse's (1987) competition measure, $h$-statistics, in 45 countries. Their findings suggest that more competitive banking systems are less prone to experience a systemic crisis and exhibit increased time to crises. De Nicolo et al. (2003) used data on the 500 largest financial firms and large banks in 90 countries in order to test the effect of bank concentration on bank stability. They found that highly concentrated banking systems have more systematic risk than less concentrated banking systems.

Ruiz-Porras (2008) studied how competition might affect the bank fragility by using logit models ${ }^{3}$. He found evidence that banking concentration is not a significant determinant for bank stability. These findings contradict the study by Beck et al. (2006), which considers banking concentration is an important determinant of banking stability. Similar to those findings, Boyd and De Nicolo (2005) claimed that if the banking market is more concentrated, the risk of failure would increase. Therefore, higher loan rates would imply higher bankruptcy risk. Cipollini and Fiordelisi (2009) investigated European banking systems by using a dataset consisting of 180 commercial banks within 25 European Union countries. They employed panel probit regression estimates with the generalised method of moments approach and found similar results with Boyd and De Nicolo's (2005) findings. They claimed that bank concentration increases the financial distress for $25 \mathrm{EU}$ countries.

Some studies show mixed results about the effects of bank concentration on bank stability. By using data from 23 developed countries, Berger et al. (2009) studied bank competition and the financial stability. Their result supports not only the "competitionfragility" view but also "competition-stability". They found that banks with a higher degree of market power, which occurs in concentrated banking systems, have less overall risk exposure. On the other hand, their findings support that market power increases loan risk in these countries. Allen and Gale (2004) consider a variety of different models of competition and bank stability. They analysed the effects of bank concentration on bank stability with the general equilibrium models of financial intermediaries and markets. They concluded that greater competition in the banking sector may be good for efficiency, but may be troubled for financial stability. Finally, Jimenez et al. (2007) investigated the effects of bank concentration in the Spanish banking system. They also detected mixed results, such as standard measures of market concentration does not affect non-performing loans. However, when they used Lerner indexes based on bankspecific interest rates, they found that the relationship was negative.

\footnotetext{
${ }^{2}$ Chang et al. (2008) investigated the Brazilian banking system to test the relationship between the non-performing loans and the bank concentration, and Deltuvaite (2010) investigated this relationship for 160 countries.

${ }^{3}$ Ruiz-Porras (2008) used banking market structure, bank-like institutions, financial structure and development variables for 47 countries between 1990 and 1997.
} 
In the empirical literature, these mixed results can be explained by two views. The first view is that the bank concentration may reduce the NPLs by enhancing market power and boosting bank profits, so that high profits can provide a "buffer" against adverse shocks (Hellman et al. 2000; Matutes, Vives 2000; Allen, Gale 2000; Beck et al. 2006). An opposite view can be counted as a more concentrated banking system may lead to less credit rationing (Caminal, Matutes 2002; Body, De Nicolo 2005). Since both of the views may hold true, the relationship between bank concentration and banking fragility can be found as ambiguous. Thus, the long-run effect of bank concentration should also be tested for a set of panel countries as well as for individual countries.

In this paper, the relationship between the bank concentration and the NPLs is investigated for ten CEE countries. These countries are ideal developing countries by which to study this issue for three reasons. Firstly, the CEE countries inherited underdeveloped and badly managed banks from the past. During the transition, the banking systems underwent a rapid change in these countries. Secondly, these countries experienced several banking crises after $1995 \mathrm{~s}^{4}$. Thirdly, only very few empirical papers have focussed on the determinants of the NPLs while considering the effect of bank concentration in the transitional economies. This paper aims to fill the gap in the literature on the effects of bank concentration in the CEE countries with the short- and long-run effects. The shortrun effect is tested with the generalised method of moments-system (GMM-system) and instrumental variable (IV) approaches, and the long-run effect is tested with the fully modified ordinary least square (FMOLS) approach ${ }^{5}$. The empirical analysis shows that the bank concentration is an insignificant factor on the NPLs, in either in the short-run or in the long-run for the panel data set. On the other hand, the individual FMOLS results show that bank concentration reduces the NPLs in Estonia, Latvia, and Slovakia, and increases the NPLs in Bulgaria, Croatia, Lithuania, Poland, and Slovenia. For positive effect, a one percentage increase in the bank concentration increases NPLs in the range of $0.06-0.86$ percentage points, and for negative effect, a one percentage increase in the bank concentration reduces $N P L s$ in the range of $0.24-0.34$ percentage points. These findings are also robust in controlling several factors, including additional control variables. Regarding to this evidence, the bank concentration does not reduce the credit risk for all of the CEE countries, and the relationship between the bank concentration and the NPLs is found to be ambiguous in the CEE countries.

The remainder of the paper is organised as follows. Section 1 presents the determinants of the NPLs. Section 2 provides the methodologies of the GMM-system, the IV, and the FMOLS. Section 3 describes the data. Section 4 presents empirical results on the effect of bank concentration, and section 5 presents robustness check. Finally, the last section concludes the study.

\footnotetext{
${ }^{4}$ The beginning and ending period of the banking crises in CEE countries as follows (Laeven, Valencia 2010): Bulgaria (1996-1997), Croatia (1997-1998), Czech Republic (1996-2000), Estonia (1992-1994), Hungary (1991-1995), Latvia (2008- ..), Lithuania (1995-1996), Poland (1992-1994), Slovakia (1998-2002), and Slovenia (1992, 2008-...).

${ }^{5}$ If the variables are cointegrated, it is not necessary to check the short-run affects using OLS or other methods. In this study, we check the short-run effect as robustness check in the short-run.
} 


\section{The determinants of NPLs}

The first step of the empirical analysis for the link between the bank concentration and the NPLs is to determine the control macroeconomic variables that can affect $N P L s^{6}$. In an early study, Keeton and Morris (1987) showed that the economic conditions significantly explain the NPLs. Sinkey and Greenwalt (1991) examined the macroeconomic factors that explain NPLs in U.S. commercial banks and they found that high interest rates, lending rates and volatile funds that have impact on the NPLs. Demirguc-Kunt and Detragiache (1998) investigated the effect of macroeconomic variables on the banking crises $^{7}$. They select GDP growth, terms of trade, changes in foreign exchange rates, real interest rates, inflation, and government budget surplus/GDP ratio as the control macroeconomic variables. They found that GDP growth has a negative impact, and real interest rates and inflation have a positive impact on the NPLs. Salas and Saurina (2002) compared the determinants of NPLs for Spanish commercial and savings banks and they use both macroeconomic and individual bank level variables, such as GDP growth rate, credit or branch expansion, inefficiency, size, net interest margin, capital ratio, and market power. Arpa et al. (2001) and Jakubik (2007) focus on developing macro models for financial stability purposes. They use GDP growth, nominal interest rates, and inflation as explanatory variables relating to the indicator of the NPLS in the economy. Louzis et al. (2012) investigated the effect of macro and micro variables on the NPLs, and they found that NPLs can be explained mainly by macroeconomic variables such as GDP growth, unemployment, and interest rates.

Only very few empirical papers have to date focused on the determinants of NPLs in transitional economies. Festic and Beko (2008) employed the vector autoregression approach for the NPLs dynamics in the five CEE countries and they concluded that GDP growth, foreign direct investment growth, real interest rates, and credit growth are significant macroeconomic variables. Festic et al. (2009) used panel estimates to explain the NPLs, by introducing macroeconomic and banking sector variables. They found that credit/asset ratio and gross fixed capital formulation have a positive impact on the NPLs, and that deposit/loan ratio, exports of goods and services, real effective exchange rate, and long-run (real) interest rates have a negative impact on the NPLs. Festic et al. (2011) tested the determinants of the NPLs for the same five CEE countries by using instrumental variable (2SLS) approach. Their estimates support the view that the growth of credit and amount available to finance may harm banking performance. Nkusu (2011) determined the macroeconomic factors that affect NPLs: GDP growth, unemployment, changes in house prices, changes in equity prices, inflation, nominal effective exchange rates, interest rates, and credit growth. Foos et al. (2010) tested the effect of loan growth on the riskiness and profitability of banks in 16 major countries. In contrast to previous studies, they found that loan growth has a negative impact on the riskiness and profitability of banks.

\footnotetext{
${ }^{6}$ The NPLs are initially affected by other macroeconomic variables and we should estimate a multiple regression where the independent variables are bank concentration and the control macroeconomic variables.

${ }^{7}$ One of their definitions of the banking crises is that the ratio of the NPLS in the banking system exceeds ten percent.
} 
The set of macroeconomic determinants of the NPLs consists of gross fixed capital formulation $(G f c)$, exports of goods and services (Export), official exchange rate growth as LCU per US\$ (Exchrate), the credit/deposit ratio (Credit/Deposit), unemployment rate as a percentage of total labour force (Unemp), the percentage of number of foreign banks in the banking system (FBanks); and these variables are in line with Festic et al. (2009). Nevertheless, the Unemp instead of interest rates, Credit/Deposit ratio instead of credit/asset and deposit/loan ratios are used in this study. The Unemp is one of the major determinants of the NPLs, as stated by Nkusu (2011). Credit/Deposit ratio is found as a more appropriate control macroeconomic variable, as it represents the usage of deposits by the banks. The FBanks ratio is added to control the effect of foreign bank entry ${ }^{8}$ on the NPLs via credit selection performance. To check for potential endogeneity of the bank concentration, we also estimate 2SLS regression with a number of instrumental variables. Selected instruments should be correlated with the explanatory variable and uncorrelated with the error term. Firstly, following Festic et al. (2011) and Festic and Kavkler (2012), banking sector development index of European Bank for Reconstruction and Development (EBRD Index) is used. Secondly, bank capital to total assets ratio (BCap) is selected ${ }^{9}$. It is expected that an increase in the ERBD index and the $B C a p$ will effect concentration in the banking sector. Thirdly, following Klomp and Haan (2012), economic freedom index of the Fraser institute (Freedom) is used. An increase in the Freedom will accelerate competition in the banking sector and this will result in diminishing concentration in the banking sector. We also checked that these three instruments are not correlated with the dependent variable (NPLs). In our estimation, IV approach will serve a robustness check of the pooled OLS and GMM-systems estimations. In addition, the panel data regression with additional control variables is tested to find out if the estimated parameters are robust or not. These additional control variables are difference between the lending and deposit rates (Spread) which is selected as a proxy for interest rate, stock market capitalisation / GDP ratio (Stock), GDP growth rate $(G d p)$, and foreign direct investment to GDP ratio $(F d i)^{10}$. It is expected that Spread should increase the NPLs as financial burden of the firms increases, and the Stock, the GDP, and the Fdi should decrease NPLs as growth and investment strength the firms' operational performance. Our model without additional control variables provided by the following function:

$$
N P L s=f\left\{\begin{array}{c}
+/- \\
\beta_{1} \text { BankCons, } \beta_{2} G f c, \beta_{3} \text { Export, } \beta_{4} \text { Exchrate, } \beta_{5} \text { Unemp, } \beta_{6} \text { Credit/Deposit, } \beta_{7} \text { FBanks }
\end{array}\right.
$$

where the NPLs is the share of non-performing loans to total bank loans, the BankCons

\footnotetext{
${ }^{8}$ Claessens and Laeven (2004) found that greater foreign bank presence can make for more competitive banking systems.

${ }^{9}$ Festic et al. (2011), Festic and Kavkler (2012) use capital adequacy ratio (measured as capital to risk weighted assets). Due to insufficient number of observation, we use capital to total assets ratio as a proxy for this variable.

${ }^{10}$ We have small sample $(\mathrm{N}=10, \mathrm{~T}=10)$ and there can be degrees of freedom problem with additional control variables. Therefore, we check FMOLS results by excluding existing control variables.
} 
is the bank concentration ratio measured by the assets share of the three largest banks in the total assets of the banking system. A negative relationship between the NPLs and the $G f c$, the Export, the Exchrate, the FBanks can be expected according to Festic et al. (2009), and a positive link between the NPLs and the Unemp can be anticipated according to Nkusu (2011).

\section{Methodology}

In this section, the GMM-system, the IV and the FMOLS approaches are clarified. The GMM-system and the IV approaches allow us to estimate the short-run effect of the bank concentration, whereas the FMOLS allows us to estimate the long-run and individual country effect of bank concentration.

\subsection{The short-run panel estimates}

The effect of bank concentration on non-performing loans can be estimated with the following panel ordinary least square regression (Pooled OLS):

$$
D(N P L s)_{i t}=\alpha_{0}+\beta_{1} D(\text { BankCons })_{i t}+\beta_{k} D\left(x_{k}\right)_{i t}+\varepsilon_{i t},
$$

where the $N P L s_{i t}$ is non-performing loans in the ith country, the BankCons $s_{i t}$ is bank concentration; $x_{i t}$ is a set of control macroeconomic variables; $D(.$.$) is the difference$ in growth rates in each variable, and $\varepsilon_{i t}$ is the error term. The current year's nonperforming loans are also dependent on the previous year's non-performing loans, as the banks cannot clear all the non-performing loans in one year. In this case, the lag of the dependent variable should be added to regression. The pooled OLS regression has potential bias because the previous year's non-performing loans will be correlated with the individual specific effect. Besides, if the variables are cointegrated, short-run affect can only be checked using panel vector error correction or dynamic panel data models. For this reason, the effect of bank concentration on non-performing loans is tested with the dynamic panel data regression based on the GMM-system, which was developed by Arellano and Bover (1995), Blundell and Bond (1998) ${ }^{11}$. The dynamic panel data model for the effect of bank concentration on the non-performing loans can be defined as:

$$
\begin{aligned}
& D(N P L s)_{i t}=\alpha_{0}+\alpha_{1} D(N P L s)_{i(t-1)}+\beta_{1} D(\text { BankCons })_{i t}+\beta_{2} D(G f c)_{i t}+\beta_{3} D(\text { Export })_{i t}+ \\
& \beta_{4} D(\text { Exchrate })_{i t}+\beta_{5} D(\text { Unemp })_{i t}+\beta_{6} D(\text { Credit / Deposit })_{i t}+\beta_{7} D(\text { FBanks })_{i t} \varepsilon_{i t},
\end{aligned}
$$

in which, $D(\ldots)$ is the difference in growth rates for the GMM-system estimates.

For a robustness check, we estimate panel data regression with the IV approach for the short-run effect. An efficient IV for panel data regression model is proposed by Hausman and Taylor (1981) and Anderson and Hsiao (1981) ${ }^{12}$. We employ the IV with panel data proposed by Anderson and Hsiao (1981) by treating bank concentration as

${ }^{11}$ The GMM-system approach produces more efficient dynamic panel data estimators than the GMM in differences approach proposed by Arellano and Bond (1991) since the GMM-system estimator reduces the potential biases arising from the instruments.

${ }^{12}$ Blundell and Bond (1998) note that both the GMM-difference and IV estimators suffer from a weak instrument problem; therefore, the GMM-system approach is more efficient than these estimators. 
endogenous variable. The EBRD Index, the BCap, and the Freedom are selected as instruments. Stata routine xtivreg $2^{13}$ is applied for the IV with panel data. Over identification of all instruments is checked with Sargan (1958) test, and the correlation with the excluded instruments and the endogenous variable is checked with Anderson (1984) canonical correlation likelihood ratio test (Anderson canon. Corr.).

\subsection{The long-run panel estimates}

Prior to the FMOLS test, the long-run equilibrium relationship should be tested with the panel cointegration analysis. Pedroni $(1999,2004)$ considers the following time series:

$$
y_{i t}=\alpha_{0}+\delta_{i} t+\beta_{1} x_{1 i, t}+\ldots .+\beta_{M i} x_{M i, t}+\varepsilon_{i, t},
$$

where $M$ is the number of regressors, $t$ is time period, and $\alpha_{i}$ and $\delta_{i}$ allow for the possibility of country specific fixed effects and deterministic trends. Let $\varepsilon_{i t}$ be the estimated residuals, which represents deviations from the long-run relationship. The null hypothesis of no cointegration is tested with the following regression model:

$$
\hat{\varepsilon}_{i, t}=\hat{\rho}_{i} \hat{\varepsilon}_{i, t}+\hat{u}_{i, t} .
$$

Evidence in favour of cointegration is provided when $\varepsilon_{i t}$ is found to be stationary. Pedroni $(1999,2004)$ has proposed seven within- and between-dimension-based statistics with the null hypothesis of no cointegration. The four within-dimension-based statistics are the panel $v$, the panel $\rho$, the panel $P P$, and the panel $A D F$, which represent the non-parametric variance ratio, Student's $t$-statistics, Phillips-Perron $\rho$ (Phillips, Perron 1988), and parametric statistics based on Augmented Dickey-Fuller (Dickey, Fuller 1981), respectively. The three between-dimension statistics are the group $\rho$, the group $P P$, and the group $A D F$. These three statistics simply average the individually estimated coefficients for each member. The distribution of these panel cointegration statistics are asymptotically standard normal, and these tests contain individual specific short-run dynamics, individual specific fixed effects-deterministic trends, and individual specific slope coefficients. For the between-dimension-based statistics, the null hypothesis is $\rho_{i}=1$ against $\rho_{i}=\rho<1$ for all $i$, while for the within-dimension-based statistics, the null hypothesis is $\rho_{i}=1$ against $\rho<1$ for all $i$.

Once the panel cointegration is established, the long-run cointegrating coefficients can be estimated using the FMOLS approach proposed by Pedroni $(2000,2001)^{14}$. Following Pedroni $(2000,2001)$, the between-dimension FMOLS for the heterogeneous cointegrated panel is estimated ${ }^{15}$. The FMOLS estimator is consistent and efficient, even with a small sample size ${ }^{16}$. This approach also corrects the standard panel OLS bias because of the endogeneity and the serial correlation of regressors. Consider the following cointegrated system for a panel of $i=1,2,3, \ldots, N$ countries over time $t$ :

\footnotetext{
13 This routine is developed by Schaffer (2008).

${ }^{14}$ Banerjee (1999) states that the FMOLS and DOLS are asymptotically equivalent for more than 60 observations. This study contains 600 observations in the panel data set.

${ }^{15}$ Pedroni (2000) shows that the between-dimension FMOLS is better than the within-dimension FMOLS.

${ }^{16}$ Our sample consist of $\mathrm{N}=10$, and $\mathrm{T}=10$.
} 


$$
\begin{gathered}
y_{i, t}=\alpha_{i}+\beta_{i, t} x_{i, t}+\mu_{i, t}, \\
x_{i, t}=x_{i, t-1}+\varepsilon_{i, t}
\end{gathered}
$$

the vector error terms $\xi_{i, t}=\left(\mu_{i, t}, \varepsilon_{i, t}\right)$ are stationary with an asymptotic covariance matrix $\Omega_{i}=L_{i} L_{i}^{\prime}{ }^{17}$, where $L_{i}$ is the lower triangular decomposition of $\Omega_{i}{ }^{18}$. Thus, the variables $y_{i, t}$ and $x_{i, t}$ are cointegrated for $i=1,2,3, \ldots, N$, with cointegrating vector $\beta$. Using this notation, the group-mean panel FMOLS estimator is presented as follows:

$$
\hat{\beta}_{G F M}^{*}=N^{-1} \sum_{i=1}^{N}\left(\sum_{t=1}^{T}\left(x_{i, t}-\bar{x}_{i}\right)^{2}\right)^{-1}\left(\sum_{t=1}^{T}\left(x_{i, t}-\bar{x}_{i}\right) y_{i, t}^{*}-T \hat{\gamma}_{i}\right),
$$

in which, $\bar{x}_{i}$ refers to the individual specific mean, $T$ is the number of sample observations over time, $y_{i, t}^{*}=\left(y_{i, t}-\bar{y}_{i, t}\right)-\frac{\hat{\Omega}_{21, i}}{\hat{\Omega}_{22, i}} \Delta x_{i, t}$, and $\hat{y}_{i} \equiv \hat{\Gamma}_{21, i}+\hat{\Omega}_{21, i}^{0}-\frac{\hat{\Omega}_{21, i}}{\hat{\Omega}_{22, i}}\left(\hat{\Gamma}_{22, i}+\hat{\Omega}_{22, i}^{0}\right)$. The $t$-statistics for the group-mean panel FMOLS estimator $\left(\hat{\beta}_{G F M}^{*}\right)$, based on the between-dimension of the panel, is given by:

$$
t_{\beta_{G F M}^{*}}=N^{-1 / 2} \sum_{i=1}^{N}\left(\left(\beta_{F M, i}^{*}-\beta_{0}\right)\left(\hat{\Omega}_{11, i}^{-1} \sum_{t=1}^{T}\left(x_{i, t}-\bar{x}_{i}\right)^{2}\right)^{1 / 2},\right.
$$

where $\beta_{F M, i}^{*}$ is the conventional FMOLS estimator, and $t_{\beta_{G F M}^{*}}$ converges to the standard normal distribution as $N \rightarrow \infty$ and $T \rightarrow \infty$.

\section{Data}

The sample consists of ten CEE countries: Bulgaria, Croatia, Czech Republic, Estonia, Hungary, Latvia, Lithuania, Poland, Slovakia, and Slovenia. The data is annual for a period of ten years between 2000 and 2009, and the BankCons and the Credit/Deposit are obtained from Beck et al. (2012) and the NPLs; the Gfc, the Export, the Exchrate, and the Unemp are obtained from the World Bank, CD-ROM 2010, and the FBanks is obtained from the European Bank for Reconstruction and Development (EBRD). The bank concentration is measured as the ratio of the three largest banks' assets to total banking assets. The non-performing loans are measured as the non-performing loans to total gross loans. Instrumental and robustness check variables as the EBRD index, the BCap, Freedom, the Spread, the Stock, the Gdp, and the Fdi are obtained from Beck et al. (2012), the World Bank CD-ROM 2010, and the European Bank for Reconstruction and Development (EBRD).

Figure 1 shows the NPLs ratio dynamics in the CEE countries for the last 10 years. Interestingly, the NPLs tend to move together in these countries, both in the recession and in the expansion period. The NPLs of these countries declined during 2000-2008, yet increased again after the global economic recession in 2008. Among others, Czech

${ }^{17} \Omega_{i}$ can also be decomposed as $\Omega_{i}=\Omega_{i}^{0}+\Gamma_{i}+\Gamma_{i}^{\prime}$, where $\Omega_{i}^{0}$ is the contemporaneous covariance and $\Gamma_{i}$ is a weighted sum of autocovariances.

${ }^{18}$ Their elements are $L_{11, i}=\left(\Omega_{11, i}-\Omega_{21, i}^{2} / \Omega_{22, i}\right)^{1 / 2}, L_{12, i}=0, L_{21, i}=\Omega_{21, i} / \Omega_{22, i}^{1 / 2}$, and $L_{22, i}=\Omega_{22, i}^{1 / 2}$. 


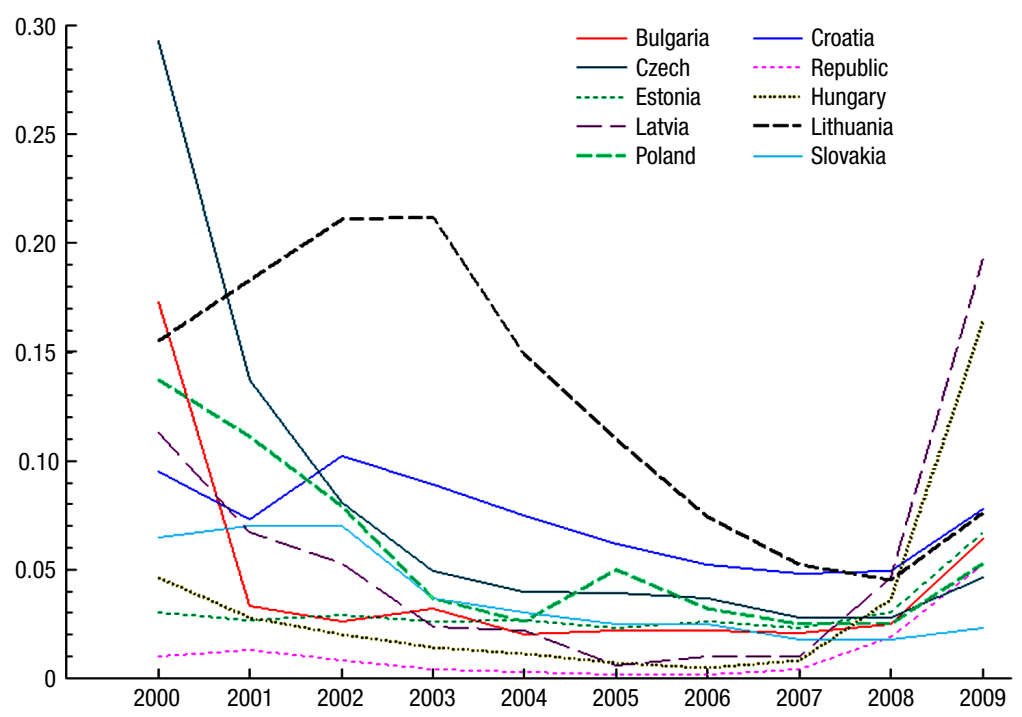

Fig. 1. NPLs ratio dynamics in the CEE countries

Republic, Bulgaria, and Slovakia had the highest NPLs ratio in 2000s, and by 2008, the NPLs ratio dropped to around five percent for all of the countries. Moving in the same direction in the last ten years shows that the NPLs ratio may not only depend on the internal factors but also the global factors, such as world economic growth, and global economic stability.

Table 1 reports the descriptive statistics for the NPLs, the bank concentration, and the selected instrumental and robustness check variables in the CEE countries. Both of the bank concentration and the NPLs are different among countries and there are wide differences in terms of standard deviations. The average ratio of the NPLs is five percent and it is between one and eight percent; the average ratio of bank concentration is 69 percent and it is between 54 and 95 percent. Selected instrumental and robustness check variables are also different among countries. Table 2 reports the cross correlations among the dependent, the explanatory, and the instrumental variables. Contrary to the expectations, there is a positive correlation between the NPLs and the BankCons. Cross correlations among the explanatory variables are less than $\% 80$, indicating that the probability of multicollinearity among the explanatory variables is very low.

Before proceeding to panel data analysis, unit root tests should be undertaken in order to check the stationary characteristics of the variables. The stationary properties of the panel data are tested with Levin et al. (2002, LLC) and Im et al. (2003, IPS) panel unit root tests, and it is found that all the variables are integrated of order zero at a difference in at least one test ${ }^{19}$.

\footnotetext{
${ }^{19}$ Results of the panel unit root tests are not reported to conserve space, but are available from the author upon request.
} 
Table 1. Descriptive statistics

Dependent and independent variables

\begin{tabular}{lcccccccc}
\hline & NPLs & BankCons & Gfc & Export & Exchrate & Unemp & Credit/Deposit & FBanks \\
\hline Bulgaria & 0.04 & 0.58 & 0.12 & 0.05 & -0.02 & 0.12 & 0.38 & 0.72 \\
& $(0.05)$ & $(0.14)$ & $(0.16)$ & $(0.19)$ & $(0.09)$ & $(0.05)$ & $(0.25)$ & $(0.03)$ \\
\hline Croatia & 0.07 & 0.60 & 0.07 & 0.04 & -0.03 & 0.13 & 0.56 & 0.47 \\
& $(0.02)$ & $(0.03)$ & $(0.10)$ & $(0.08)$ & $(0.09)$ & $(0.04)$ & $(0.14)$ & $(0.05)$ \\
\hline Czech Rep. & 0.08 & 0.67 & 0.03 & 0.10 & -0.05 & 0.07 & 0.40 & 0.74 \\
& $(0.08)$ & $(0.12)$ & $(0.05)$ & $(0.09)$ & $(0.10)$ & $(0.01)$ & $(0.09)$ & $(0.05)$ \\
\hline Estonia & 0.01 & 0.95 & 0.07 & 0.06 & -0.02 & 0.09 & 0.64 & 0.72 \\
& $(0.02)$ & $(0.04)$ & $(0.18)$ & $(0.13)$ & $(0.09)$ & $(0.03)$ & $(0.28)$ & $(0.14)$ \\
\hline Hungary & 0.03 & 0.70 & 0.03 & 0.11 & -0.01 & 0.07 & 0.46 & 0.71 \\
& $(0.01)$ & $(0.12)$ & $(0.05)$ & $(0.07)$ & $(0.12)$ & $(0.01)$ & $(0.14)$ & $(0.06)$ \\
\hline Latvia & 0.03 & 0.54 & 0.07 & 0.06 & -0.01 & 0.11 & 0.55 & 0.50 \\
& $(0.05)$ & $(0.03)$ & $(0.19)$ & $(0.09)$ & $(0.05)$ & $(0.04)$ & $(0.32)$ & $(0.09)$ \\
\hline Lithuania & 0.05 & 0.80 & 0.05 & 0.09 & -0.04 & 0.11 & 0.34 & 0.45 \\
& $(0.06)$ & $(0.02)$ & $(0.19)$ & $(0.10)$ & $(0.06)$ & $(0.04)$ & $(0.22)$ & $(0.09)$ \\
\hline Poland & 0.13 & 0.66 & 0.04 & 0.09 & -0.02 & 0.15 & 0.31 & 0.78 \\
& $(0.06)$ & $(0.12)$ & $(0.09)$ & $(0.09)$ & $(0.13)$ & $(0.05)$ & $(0.07)$ & $(0.08)$ \\
\hline Slovakia & 0.06 & 0.80 & 0.04 & 0.10 & -0.06 & 0.15 & 0.39 & 0.65 \\
& $(0.04)$ & $(0.06)$ & $(0.08)$ & $(0.05)$ & $(0.10)$ & $(0.04)$ & $(0.07)$ & $(0.09)$ \\
\hline Slovenia & 0.04 & 0.62 & 0.05 & 0.08 & 0.01 & 0.06 & 0.55 & 0.34 \\
& $(0.02)$ & $(0.08)$ & $(0.04)$ & $(0.05)$ & $(0.10)$ & $(0.01)$ & $(0.21)$ & $(0.09)$ \\
\hline Average & 0.05 & 0.69 & 0.06 & 0.08 & -0.03 & 0.11 & 0.46 & 0.61 \\
\hline Robustness
\end{tabular}

Robustness check and instrumental variables

\begin{tabular}{lccccccc}
\hline & Spread & Gdp & Stock & Fdi & EBRD Index & BCap & Freedom \\
\hline Bulgaria & 0.06 & 0.05 & 0.30 & 0.14 & 3.48 & 0.11 & 6.67 \\
& $(0.01)$ & $(0.04)$ & $(0.38)$ & $(0.09)$ & $(0.30)$ & $(0.03)$ & $(0.68)$ \\
\hline Croatia & 0.09 & 0.03 & 0.45 & 0.06 & 3.80 & 0.11 & 6.29 \\
& $(0.01)$ & $(0.03)$ & $(0.35)$ & $(0.02)$ & $(0.29)$ & $(0.02)$ & $(0.19)$ \\
\hline Czech Rep. & 0.04 & 0.03 & 0.29 & 0.06 & 3.81 & 0.06 & 6.95 \\
& $(0.00)$ & $(0.03)$ & $(0.13)$ & $(0.03)$ & $(0.23)$ & $(0.00)$ & $(0.25)$ \\
\hline Estonia & 0.03 & 0.05 & 0.31 & 0.10 & 3.88 & 0.10 & 7.68 \\
& $(0.01)$ & $(0.08)$ & $(0.05)$ & $(0.05)$ & $(0.15)$ & $(0.02)$ & $(0.16)$ \\
\hline Hungary & 0.02 & 0.02 & 0.27 & 0.15 & 4.00 & 0.09 & 7.22 \\
& $(0.02)$ & $(0.04)$ & $(0.06)$ & $(0.18)$ & $(0.00)$ & $(0.00)$ & $(0.34)$ \\
\hline Latvia & 0.05 & 0.05 & 0.09 & 0.04 & 3.65 & 0.08 & 7.04 \\
& $(0.02)$ & $(0.09)$ & $(0.03)$ & $(0.03)$ & $(0.30)$ & $(0.00)$ & $(0.24)$ \\
\hline Lithuania & 0.04 & 0.05 & 0.20 & 0.04 & 3.41 & 0.09 & 7.05 \\
& $(0.02)$ & $(0.07)$ & $(0.08)$ & $(0.02)$ & $(0.32)$ & $(0.01)$ & $(0.44)$ \\
\hline Poland & 0.03 & 0.04 & 0.30 & 0.04 & 3.50 & 0.08 & 6.59 \\
& $(0.03)$ & $(0.02)$ & $(0.17)$ & $(0.01)$ & $(0.21)$ & $(0.01)$ & $(0.35)$ \\
\hline Slovakia & 0.04 & 0.04 & 0.08 & 0.05 & 3.51 & 0.08 & 7.26 \\
& $(0.02)$ & $(0.05)$ & $(0.01)$ & $(0.04)$ & $(0.26)$ & $(0.02)$ & $(0.53)$ \\
\hline Slovenia & 0.04 & 0.03 & 0.40 & 0.03 & 3.30 & 0.09 & 6.74 \\
& $(0.01)$ & $(0.04)$ & $(0.37)$ & $(0.02)$ & $(0.00)$ & $(0.01)$ & $(0.13)$ \\
\hline Average & 0.05 & 0.04 & 0.27 & 0.07 & 3.63 & 0.09 & 6.95 \\
\hline
\end{tabular}

Notes: Standard errors of the coefficients are shown in parentheses. 


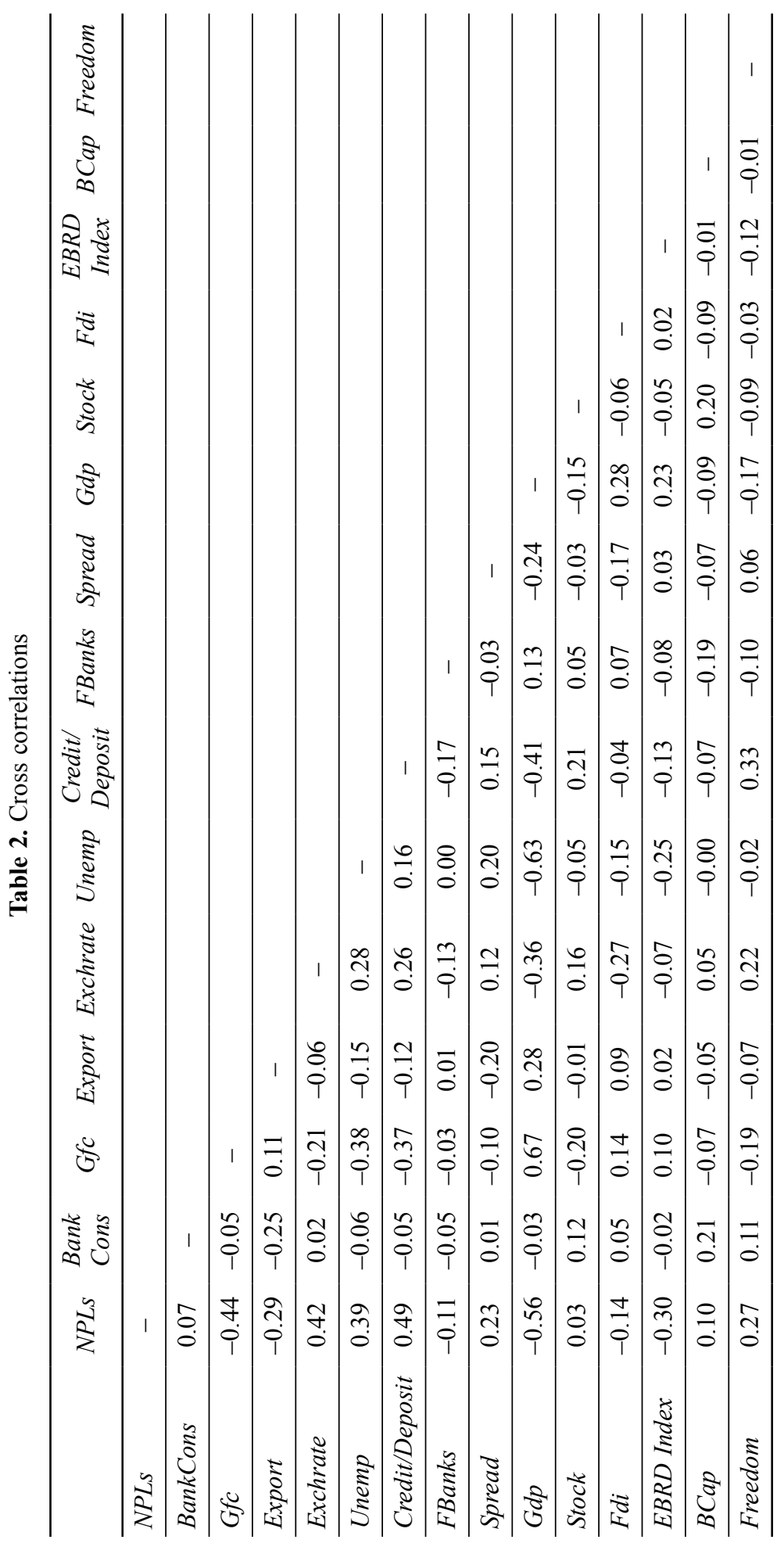




\section{Empirical results}

The short-run effects of bank concentration on the non-performing loans are estimated with the pooled OLS, the GMM-system, and 2SLS estimates. The results are shown in Table 3. The pooled OLS regression shows that the bank concentration is not a statistically significant determinant of the NPLS. Since the pooled OLS is not an efficient panel data estimation technique, we also test the effect of bank concentration with the GMM-system and instrumental variable approaches. Three diagnostic test statistics are reported for the GMM-system estimation: (1) Wald test of joint significance, (2) Sargan

Table 3. Panel data estimates

\begin{tabular}{|c|c|c|c|}
\hline & Pooled OLS (RE) & GMM-system & $\begin{array}{l}\text { Instrumental variable } \\
\text { (2SLS) }\end{array}$ \\
\hline Constant & $\begin{array}{l}-0.01 * * \\
(2.41)\end{array}$ & $\begin{array}{l}-0.00 \\
(0.03)\end{array}$ & - \\
\hline$D(N P L s(-1))$ & - & $\begin{array}{c}0.27 * * * \\
(2.82)\end{array}$ & $\begin{array}{l}0.23 * * \\
(2.27)\end{array}$ \\
\hline$D$ (BankCons) & $\begin{array}{c}0.02 \\
(0.57)\end{array}$ & $\begin{array}{c}0.00 \\
(0.22)\end{array}$ & $\begin{array}{l}-0.00 \\
(0.04)\end{array}$ \\
\hline$D(G f c)$ & $\begin{array}{c}-0.05 * * \\
(2.36)\end{array}$ & $\begin{array}{l}-0.03 \\
(1.30) \\
\end{array}$ & $\begin{array}{c}-0.03 \\
(1.18) \\
\end{array}$ \\
\hline$D($ Export $)$ & $\begin{array}{l}-0.05 \\
(1.45)\end{array}$ & $\begin{array}{c}-0.03^{*} \\
(1.80)\end{array}$ & $\begin{array}{l}-0.02 \\
(1.21)\end{array}$ \\
\hline$D$ (Exchrate) & $\begin{array}{l}0.08^{* * *} \\
(2.61)\end{array}$ & $\begin{array}{l}0.05^{* *} \\
(1.94)\end{array}$ & $\begin{array}{l}0.05 * * \\
(2.00)\end{array}$ \\
\hline D(Unemp) & $\begin{array}{l}0.27^{*} \\
(1.14)\end{array}$ & $\begin{array}{c}0.60 * * * \\
(4.90)\end{array}$ & $\begin{array}{c}0.51 * * * \\
(3.41)\end{array}$ \\
\hline D(Credit/Deposit) & $\begin{array}{l}0.10^{* * *} \\
(2.64)\end{array}$ & $\begin{array}{c}0.04 \\
(1.06)\end{array}$ & $\begin{array}{c}0.04 \\
(1.18)\end{array}$ \\
\hline D(FBanks) & $\begin{array}{l}-0.02 \\
(0.60)\end{array}$ & $\begin{array}{c}0.06 \\
(1.19)\end{array}$ & $\begin{array}{c}0.01 \\
(0.33)\end{array}$ \\
\hline F test & $33.61 * * *$ & - & $12.48 * * *$ \\
\hline Hausman test & 0.99 & - & - \\
\hline Wald test & - & $228.27 * * *$ & - \\
\hline Sargan test & - & 0.13 & 0.23 \\
\hline Anderson canon. Corr. & - & - & $0.02 * *$ \\
\hline Arellano-Bond test for AR(1) & - & 0.00 & - \\
\hline Arellano-Bond test for $\mathrm{AR}(2)$ & & 0.97 & - \\
\hline
\end{tabular}

Notes: $* * *, * * *$ indicate a significance of $10 \%, 5 \%$, and $1 \%$ respectively. The numbers in brackets are the $t$-statistics. The Sargan test shows $p$-value for overidentification test of all instruments, the Anderson canon. Corr. test shows $p$-value for under identification test for the instruments, and AR(1), and AR(2) show $p$-values of Arellano-Bond autocorrelation tests. The null hypothesis for AR(1) is that the first-differenced regression error term has no first-order serial correlation, and the null hypothesis for $\operatorname{AR}(2)$ is that the first-differenced regression error term has no second-order serial correlation. Instrumental variables in 2SLS: the EBRD index, the BCap, and the Freedom. 
(1958) test of overidentifying restrictions, and (3) for zero autocorrelation up to order two. The Wald test statistics indicate that the bank concentration, the NPLs, and the control macroeconomic variables are jointly significant at a 1\% level in the GMM-system estimation. The Arellano-Bond (1991) test shows that the AR(1) test rejects the null hypothesis of no first-order autocorrelation, and that the AR(2) test does not reject the null hypothesis of no second order autocorrelation of residuals. The null hypothesis of the validity of the instruments set should be accepted based on the Sargan test. According to the GMM-system estimation, the bank concentration is not a statistically significant determinant of the NPLs. For the 2SLS, two diagnostic test statistics are reported: (1) Sargan (1958) test of overidentifying restrictions, and (2) Anderson (1984) canonical correlation likelihood ratio test. The Sargan test fail to reject the null hypotheses that our instruments are valid (p-value 0.23 ), which supports the validity of the selected instruments as the EBRD Index, the BCap, and the Freedom. The Anderson canonical correlation test shows that the null hypothesis can be rejected indicating that the model is identified and the instruments are relevant. The 2SLS panel data model shows that the bank concentration is not a statistically significant determinant of the NPLs as $t$-value of the Bankcons is 0.04. Accordingly, all the short-run panel data models show that the bank concentration is an insignificant factor for the NPLs of CEE countries.

Prior to FMOLS analysis, the long-run equilibrium relationship between the NPLs, the bank concentration, and the control macroeconomic variables should be tested with the panel cointegration analysis ${ }^{20}$. Table 4 reports both the within- and between-dimension panel cointegration test statistics. With the exception of the panel PP test, the other four test statistics reject the null hypothesis of no cointegration at the $1 \%$ significance level with a constant, and with the exception of the panel PP and the group ADF tests, the

Table 4. Panel cointegration test

\begin{tabular}{lcc}
\hline \multicolumn{1}{c}{ Test statistics $^{\mathrm{a}}$} & With a constant & No constant \\
\hline Panel $v$-statistics & $2.1006^{* *}$ & $2.172^{* *}$ \\
\hline Panel $\rho$-statistics & $-4.3317^{* * *}$ & $-3.7396^{* * *}$ \\
\hline Panel PP-statistics & 1.3229 & 0.8530 \\
\hline Panel ADF-statistics & - & $2.2049^{* *}$ \\
\hline Group $\rho$-statistics & $-5.4973^{* * *}$ & $-4.9143^{* * *}$ \\
\hline Group PP-statistics & $-15.3577^{* * *}$ & $-7.9258^{*}$ \\
\hline Group ADF-statistics & - & 0.6449
\end{tabular}

Notes: ${ }^{a}$ Statistics are asymptotically distributed as normal. The panel $\mathrm{v}$-test is right-sided, whereas the other tests are left-sided. $*, * *, * * *$ indicate a significance of $10 \%, 5 \%$, and $1 \%$ respectively. Pedroni $(1999,2004)$ residual panel cointegration test is estimated within the BankCons, the NPLs, the Gfc, the Export, the Exchrate, the Unemp, the Credit/deposit, and the FBanks ratios.

${ }^{20}$ Panel cointegration is estimated with nonstationary (level series)* unlike short-run estimates (differenced series). 
other five test statistics reject the null hypothesis of no cointegration at the $1 \%$ significance level without a constant ${ }^{21}$. Pedroni (2004) states that the panel ADF statistics have better small sample properties; therefore, our results are more reliable for the sample. Thus, following panel cointegration tests, we conclude that the NPLs, bank concentration, and the control macroeconomic variables are cointegrated for the CEE countries. Using the FMOLS, the long-run cointegrating coefficients should be estimated in order to find out the long-run relationship between the NPLs, the bank concentration, and the control macroeconomic variables.

Results for the panel group as well as the individual FMOLS estimators and $t$-statistics are reported in Table 5. For the panel group, the coefficient of the BankCons is not statistically significant, whereas the coefficients of the control macro-variables, such as

Table 5. Panel FMOLS estimates

\begin{tabular}{|c|c|c|c|c|c|c|c|}
\hline Countries & BankCons & $G f c$ & Export & Exchrate & Unemp & $\begin{array}{c}\text { Credit/ } \\
\text { Deposit }\end{array}$ & FBanks \\
\hline Bulgaria & $\begin{array}{c}0.06 * * * \\
(9.25)\end{array}$ & $\begin{array}{c}-0.08 * * * \\
(14.47)\end{array}$ & $\begin{array}{c}-0.01 * * * \\
(2.98)\end{array}$ & $\begin{array}{c}0.07 * * * \\
(7.54)\end{array}$ & $\begin{array}{c}0.39 * * * \\
(4.31)\end{array}$ & $\begin{array}{c}-0.12 * * * \\
(4.90)\end{array}$ & $\begin{array}{c}-0.32 * * * \\
(6.99)\end{array}$ \\
\hline Croatia & $\begin{array}{l}0.11 * * * \\
(24.29)\end{array}$ & $\begin{array}{c}0.23 * * * \\
(15.81)\end{array}$ & $\begin{array}{c}-0.55 * * * \\
(18.96)\end{array}$ & $\begin{array}{c}-0.23 * * * \\
(100.23)\end{array}$ & $\begin{array}{l}1.06 * * * \\
(109.80)\end{array}$ & $\begin{array}{c}0.13 * * * \\
(43.79)\end{array}$ & $\begin{array}{c}-0.14 * * * \\
(76.30)\end{array}$ \\
\hline Czech Rep. & $\begin{array}{c}0.59 \\
(1.44)\end{array}$ & $\begin{array}{c}2.45 * * * \\
(8.21)\end{array}$ & $\begin{array}{c}-1.46^{* * *} \\
(7.89)\end{array}$ & $\begin{array}{c}-3.27 * * * \\
(8.69)\end{array}$ & $\begin{array}{c}30.48 * * * \\
(8.61)\end{array}$ & $\begin{array}{c}2.48 * * * \\
(9.04)\end{array}$ & $\begin{array}{c}4.77 * * * \\
(6.96)\end{array}$ \\
\hline Estonia & $\begin{array}{c}-0.34 * * * \\
(11.28)\end{array}$ & $\begin{array}{c}0.02 \\
(6.86)\end{array}$ & $\begin{array}{c}0.01 \\
(1.08)\end{array}$ & $\begin{array}{c}0.07 * * * \\
(18.05)\end{array}$ & $\begin{array}{c}0.13 * * * \\
(7.95)\end{array}$ & $\begin{array}{c}0.02 * * * \\
(8.08)\end{array}$ & $\begin{array}{c}-0.06 * * * \\
(9.40)\end{array}$ \\
\hline Hunge & $\begin{array}{c}0.02 \\
(0.79)\end{array}$ & $\begin{array}{c}0.04 \\
(0.83)\end{array}$ & $\begin{array}{l}-0.04 \\
(0.91)\end{array}$ & $\begin{array}{c}0.02 \\
(0.59)\end{array}$ & $\begin{array}{l}1.04 * * \\
(1.86)\end{array}$ & $\begin{array}{c}0.05 \\
(1.43)\end{array}$ & $\begin{array}{l}-0.06 \\
(0.52)\end{array}$ \\
\hline Latvia & $\begin{array}{c}-0.29 * * * \\
(3.83)\end{array}$ & $\begin{array}{c}0.03 \\
(1.32)\end{array}$ & $\begin{array}{l}-0.02 \\
(0.55)\end{array}$ & $\begin{array}{c}0.12 * * * \\
(3.07)\end{array}$ & $\begin{array}{c}0.83 * * * \\
(7.44)\end{array}$ & $\begin{array}{c}0.04 * * * \\
(7.77)\end{array}$ & $\begin{array}{c}0.12 * * * \\
(2.74)\end{array}$ \\
\hline Lithuania & $\begin{array}{c}0.86^{* * *} \\
(10.43)\end{array}$ & $\begin{array}{c}-0.27 * * * \\
(11.83)\end{array}$ & $\begin{array}{c}-0.40 * * * \\
(9.95)\end{array}$ & $\begin{array}{c}0.23 * * * \\
(7.91)\end{array}$ & $\begin{array}{c}-0.52 * * * \\
(3.50)\end{array}$ & $\begin{array}{c}-0.15 * * * \\
(6.22)\end{array}$ & $\begin{array}{c}-0.14 * * * \\
(4.21)\end{array}$ \\
\hline Poland & $\begin{array}{c}0.29 * * * \\
(3.03)\end{array}$ & $\begin{array}{c}-0.26^{*} \\
(1.85)\end{array}$ & $\begin{array}{c}0.34 * * * \\
(3.49)\end{array}$ & $\begin{array}{c}0.06 \\
(1.39)\end{array}$ & $\begin{array}{c}0.88 * * * \\
(3.17)\end{array}$ & $\begin{array}{c}-0.16^{*} \\
(1.68)\end{array}$ & $\begin{array}{l}0.21^{*} \\
(1.86)\end{array}$ \\
\hline Slovakia & $\begin{array}{c}-0.24 * * * \\
(6.86)\end{array}$ & $\begin{array}{c}0.02 \\
(0.49)\end{array}$ & $\begin{array}{c}-0.11 * * * \\
(6.75)\end{array}$ & $\begin{array}{c}-0.08 * * * \\
(5.33)\end{array}$ & $\begin{array}{l}1.42 * * * \\
(30.77)\end{array}$ & $\begin{array}{c}0.32 * * * \\
(6.34)\end{array}$ & $\begin{array}{c}0.02 \\
(0.35)\end{array}$ \\
\hline Slovenia & $\begin{array}{c}0.24 * * * \\
(5.72)\end{array}$ & $\begin{array}{c}0.22 * * * \\
(2.62)\end{array}$ & $\begin{array}{c}-0.21 * * * \\
(4.77)\end{array}$ & $\begin{array}{c}0.22 * * * \\
(5.18)\end{array}$ & $\begin{array}{c}1.16^{* * *} \\
(2.92)\end{array}$ & $\begin{array}{l}-0.01 \\
(0.88)\end{array}$ & $\begin{array}{c}0.05 \\
(1.14)\end{array}$ \\
\hline Panel group & $\begin{array}{l}-0.01 \\
(0.43)\end{array}$ & $\begin{array}{c}0.24 * * * \\
(45.85)\end{array}$ & $\begin{array}{c}-0.24 * * * \\
(78.49)\end{array}$ & $\begin{array}{c}-0.28 * * * \\
(22.49)\end{array}$ & $\begin{array}{c}3.61 * * * \\
(52.08)\end{array}$ & $\begin{array}{c}0.25 * * * \\
(18.94)\end{array}$ & $\begin{array}{c}-0.44 * * * \\
(26.68)\end{array}$ \\
\hline
\end{tabular}

Notes: $*, * *, * * *$ indicate a significance of $10 \%, 5 \%$, and $1 \%$ respectively. The numbers in brackets are the $t$-statistics.

${ }^{21}$ Due to insufficient observations for a panel cointegration test with a constant, the panel ADF and the group ADF statistics cannot be estimated. 
the Gfc, the Export, the Exchrate, the Unemp, the Credit/Deposit, and the FBanks are statistically significant factors. The significance of the control macro-variables show that the long-run model is correctly established for the NPLs. Among others, the Unemp is the most important macroeconomic factor for the NPLs, and a one percentage increase in the unemployment rate increases NPLs by 3.61 percentage point for the panel group. The coefficients of the $G f c$, the Unemp, and the Credit/Deposit are positive, whereas the coefficients of the Export, the Exchrate, and the FBanks are negative for the panel group. In contrast to theory explained in the methodology section, an increase in the $G f c$ results in an increase in NPLs. These findings need to be checked for individual countries.

Although the coefficient of the BankCons is not a statistically significant factor for the panel group, the individual FMOLS results show that the bank concentration reduces the NPLs in Estonia, Latvia, and Slovakia, and increases the NPLs in Bulgaria, Croatia, Lithuania, Poland, and Slovenia. While countries on which the BankCons has a positive effect, a one percentage increase in bank concentration increases the NPLs by the range of $0.06-0.86$ percentage points, the set of countries on which the BankCons has a negative effect, a one percentage increase in bank concentration reduces the NPLs by the range of $0.24-0.34$ percentage points. This evidence reveals that the effect of bank concentration on the NPLs is ambiguous in the CEE countries. With regard to the control macroeconomic variables, the individual FMOLS results demonstrate that some of the individual variables are not statistically significant. The $G f_{c}$ is not a statistically significant factor for Estonia, Hungary, Slovakia; the Export is not a statistically significant factor for Estonia Hungary, and Latvia; the Exchrate is not a statistically significant factor for Hungary and Poland; the Credit/Deposit is not a statistically significant factor for Hungary, and Slovenia; and the FBanks is not a statistically significant factor for Slovakia and Slovenia. Among others, the Unemp is found to be the most important individual factor on the NPLs in the CEE countries.

\section{Robustness check}

In order to test for the robustness of the results, we perform separate robustness check for the short-run and the long-run estimates. Three short-run robustness checks are shown in Table 6: (a) Firstly, we estimate the panel regression with a sub-sample period, from 2007 to $2009^{22}$, in order to evaluate the effect of the global financial crises on the bank concentration-the NPLs relationship. Due to insufficient number of observations $(\mathrm{N}=10, \mathrm{~T}=3)$, this panel data is estimated with pooled OLS. Hausman (1978) test is accepted indicating that the panel data should be estimated with the fixed effect. According to the first robustness check, Wald test statistics reveal that the bank concentration, the NPLs, and the control macroeconomic variables are jointly significant at a $1 \%$

\footnotetext{
${ }^{22}$ Global financial crises erupted in the middle of 2007 and reached the most devastating effects at the end of 2009. Most of the developed and developing countries experienced a recession during the global financial crises.
} 
Table 6. Robustness check of panel data estimates

\begin{tabular}{|c|c|c|c|c|}
\hline & $\begin{array}{l}\text { Robustness } \\
\text { check (a) }\end{array}$ & $\begin{array}{l}\text { Robustness } \\
\text { check (b) }\end{array}$ & $\begin{array}{l}\text { Robustness } \\
\text { check (c) }\end{array}$ & $\begin{array}{l}\text { Robustness } \\
\text { check (d) }\end{array}$ \\
\hline Constant & $\begin{array}{c}0.01 \\
(1.13)\end{array}$ & $\begin{array}{l}-0.00 \\
(0.63)\end{array}$ & $\begin{array}{c}0.00 \\
(0.05)\end{array}$ & $\begin{array}{c}0.00 \\
(0.05)\end{array}$ \\
\hline$D(N P L s(-1))$ & - & $\begin{array}{c}0.25^{* * *} \\
(2.88)\end{array}$ & $\begin{array}{c}0.26 * * * \\
(2.72)\end{array}$ & $\begin{array}{c}0.27 * * * \\
(2.87)\end{array}$ \\
\hline D(BankCons) & $\begin{array}{c}-0.02 \\
(0.0 .65)\end{array}$ & $\begin{array}{c}0.00 \\
(0.14)\end{array}$ & $\begin{array}{c}0.01 \\
(0.41)\end{array}$ & $\begin{array}{c}0.00 \\
(0.24)\end{array}$ \\
\hline$\overline{D(G f \mathcal{c})}$ & $\begin{array}{l}-0.02 \\
(1.08)\end{array}$ & $\begin{array}{l}-0.00 \\
(0.16)\end{array}$ & $\begin{array}{l}-0.03 \\
(1.56)\end{array}$ & $\begin{array}{l}-0.02 \\
(1.22)\end{array}$ \\
\hline$D($ Export $)$ & $\begin{array}{c}0.00 \\
(0.31)\end{array}$ & $\begin{array}{l}-0.01 \\
(0.94)\end{array}$ & $\begin{array}{l}-0.03^{*} \\
(1.78)\end{array}$ & $\begin{array}{c}-0.02 \\
(1.75)^{*}\end{array}$ \\
\hline$D$ (Exchrate $)$ & $\begin{array}{c}0.01 \\
(0.56)\end{array}$ & $\begin{array}{l}0.04^{*} \\
(1.82)\end{array}$ & $\begin{array}{l}0.05 * * \\
(2.00)\end{array}$ & $\begin{array}{l}0.04 * \\
(1.83)\end{array}$ \\
\hline$D($ Unemp $)$ & $\begin{array}{c}0.90 * * * \\
(3.36)\end{array}$ & $\begin{array}{c}0.40 * * * \\
(3.15)\end{array}$ & $\begin{array}{c}0.58 * * * \\
(4.65)\end{array}$ & $\begin{array}{c}0.61 * * * \\
(4.92)\end{array}$ \\
\hline$D($ Credit/Deposit $)$ & $\begin{array}{l}-0.02 \\
(0.21)\end{array}$ & $\begin{array}{c}0.04 \\
(1.10)\end{array}$ & $\begin{array}{c}0.05 \\
(1.25)\end{array}$ & $\begin{array}{c}0.04 \\
(0.99)\end{array}$ \\
\hline D(FBanks) & $\begin{array}{l}0.25^{*} \\
(1.86)\end{array}$ & $\begin{array}{c}0.07 \\
(1.59)\end{array}$ & $\begin{array}{c}0.06 \\
(1.27)\end{array}$ & $\begin{array}{c}0.06 \\
(1.18)\end{array}$ \\
\hline$D($ Spread $)$ & - & $\begin{array}{c}0.17 \\
(1.40)\end{array}$ & - & - \\
\hline$D(G d p)$ & - & $\begin{array}{c}-0.21 * * * \\
(2.87)\end{array}$ & - & - \\
\hline$D($ Stocks $)$ & - & - & $\begin{array}{l}-0.03 \\
(1.23)\end{array}$ & - \\
\hline$\overline{D(F d i)}$ & - & - & - & $\begin{array}{c}0.00 \\
(0.28)\end{array}$ \\
\hline $\mathrm{F}$ test & $16.73 * * *$ & & & \\
\hline Wald test & - & $290.89 * * *$ & $225.51 * * *$ & $224.82 * * *$ \\
\hline Hausman test & 0.00 & - & - & - \\
\hline Sargan test & - & 0.32 & 0.21 & 0.11 \\
\hline $\begin{array}{l}\text { Arellano-Bond } \\
\text { test for AR(1) }\end{array}$ & - & 0.00 & 0.00 & 0.00 \\
\hline $\begin{array}{l}\text { Arellano-Bond } \\
\text { test for } \operatorname{AR}(2)\end{array}$ & - & 0.96 & 0.92 & 0.98 \\
\hline
\end{tabular}

Notes: This table reports robustness check for the short-run estimates. ${ }^{*}, * *$, and $* * *$ indicate significance of $10 \%, 5 \%$, and $1 \%$ respectively. The numbers in brackets are the $t$-statistics. Robustness check (a) represents the estimation for the global crisis period 2007-2009, robustness check (b) represents the estimation with the additional control variables, namely the Spread (interest rate spread) and the $G d p$ (GDP growth), robustness check (c) represents the estimation with the additional control variable, namely the Stocks (stock market capitalisation / GDP ratio), and robustness check (d) represents the estimation with the additional control variable, namely the Fdi (foreign direct investment / GDP ratio). 
level in the sub-sample period. As was the case with the full-sample estimate, the bank concentration is not a statistically significant determinant of the NPLs. All of the control macroeconomic variables, except the Unemp and the FBanks, are also statistically insignificant. In order to determine whether previous results are robust, we include additional control macroeconomic variables taken from the determinants of the NPLs literature, including, (b) the Spread, and the Gdp, (c) the Stock, and (d) the Fdi. According to these robustness checks, the GMM-system estimates show that bank concentration is not a statistically significant determinant of the NPLs. These robustness checks confirm that bank concentration does not affect the NPLs in the short-run.

Table 7 shows the robustness check in the long-run. Additional control variables provide inconsistent results with the FMOLS; therefore, the robustness checks are performed with less control macroeconomic variables. When we exclude all of the control macroeconomic variables (a), the bank concentration is insignificant factor ( $t$-value: 1.34) for the NPLs. When we add the Gfc, the Export, the Exchate (b), the Unemp, the Credit/ Deposit (c), the bank concentration is still insignificant factor ( $t$-values: 0.40 , and 0.21 respectively) for the NPLs. Same as the short-run robustness results, the long-run robustness checks confirm that bank concentration does not affect the NPLs.

Table 7. Robustness check of panel FMOLS estimates

\begin{tabular}{lccc}
\hline & Robustness check (a) & Robustness check (b) & Robustness check (c) \\
\hline BankCons & 0.03 & 0.09 & 0.08 \\
& $(1.34)$ & $(0.40)$ & $(0.21)$ \\
\hline Gfc & - & $-0.04^{* * *}$ & $0.03^{* * *}$ \\
& & $(9.83)$ & $(2.94)$ \\
\hline Export & - & $-0.07^{* * *}$ & $-0.10^{* * *}$ \\
& & $(5.28)$ & $(13.63)$ \\
\hline Exchrate & - & $0.14^{* * *}$ & $-0.02^{* * *}$ \\
& & $(10.22)$ & $(2.95)$ \\
\hline Unemp & - & - & $1.17 * * *$ \\
& - & - & $(33.47)$ \\
\hline Credit/ Deposit & & & $0.08^{* * *}$ \\
& & & $(20.56)$ \\
\hline
\end{tabular}

Notes: This table reports robustness check for the long-run estimates. Robustness check (a), (b) and (c) are the panel group FMOLS results with selected dependent variables. *, **, *** indicate a significance of $10 \%, 5 \%$, and $1 \%$ respectively. The numbers in brackets are the $t$-statistics.

\section{Conclusions}

In this paper, the relationship between bank concentration and the NPLs is investigated for ten CEE countries, including Bulgaria, Croatia, Czech Republic, Estonia, Hungary, Latvia, Lithuania, Poland, Slovakia, and Slovenia. The major contribution of this paper is to explore the effects of bank concentration in the CEE countries both in the shortand long-run. Furthermore, the effect of bank concentration is tested not only for a 
long-time period but also for the financial crises period. The short-run effect is tested with the GMM-system and the IV approaches, and the long-run effect is tested with the FMOLS approach.

The empirical analysis shows that bank concentration is an insignificant factor on the $N P L s$, either in the short-run or in the long-run for the panel data set. On the other hand, individual FMOLS results show that the bank concentration reduces the NPLs in Estonia, Latvia, and Slovakia, and increases the NPLs in Bulgaria, Croatia, Lithuania, Poland, and Slovenia. For positive effect, a one percentage increase in bank concentration increases the NPLs in the range of $0.06-0.86$ percentage points, and for negative effect, a one percentage increase in bank concentration reduces the NPLs in the range of 0.24-0.34 percentage points. According to this evidence, the bank concentration in the banking sector does not mitigate the credit risk for all of the CEE countries. These findings are also robust enough controlling several factors, including the recent financial crises period and additional control variables. As a result, the relationship between the bank concentration and the NPLs, in regards to the CEE countries, is ambiguous.

\section{Acknowledgements}

The author is grateful to the Editor, anonymous referees, Selahattin Guris, and Gokhan Akay for their extremely helpful comments and suggestions.

\section{References}

Allen, F.; Gale, D. 2000. Comparing financial systems. Cambridge, AM: MIT Press.

Allen, F.; Gale, D. 2004. Competition and financial stability, Journal of Money, Credit, and Banking 36(3): 453-480. http://dx.doi.org/10.1353/mcb.2004.0038

Anderson, T. W.; Hsiao, C. 1981. Estimation of dynamic models with error components, Journal of the American Statistical Association 76: 598-606.

http://dx.doi.org/10.1080/01621459.1981.10477691

Anderson, T. W. 1984. An introduction to multivariate statistical analysis. New York: Wiley Press.

Arellano, M.; Bond, S.R. 1991. Some tests of specification for panel data: Monte Ccarlo evidence and an application to employment equations, Review of Economic Studies 58: 277-297.

http://dx.doi.org/10.2307/2297968

Arellano, M.; Bover, O. 1995. Another look at the instrumental variable estimation of errorcomponent models, Journal of Econometrics 68: 29-51.

http://dx.doi.org/10.1016/0304-4076(94)01642-D

Arpa, M.; Giulini, I.; Ittner, A.; Pauer, F. 2001. The influence of macroeconomic developments on Austrian banks: implications for banking supervision, Working Paper No 1. Basel, Bank for International Settlements.

Banerjee, A. 1999. Panel data unit roots and cointegration: an overview, Oxford Bulletin of Economics and Statistics 61: 607-629. http://dx.doi.org/10.1111/1468-0084.61.s1.12

Beck, T.; Demirgunc-Kunt, A.; Levine, R. 2006. Bank concentration, competition, and crises: first results, Journal of Banking and Finance 30: 1581-1603.

http://dx.doi.org/10.1016/j.jbankfin.2005.05.010 
Beck, T.; Demirgunc-Kunt, A.; Levine, R. 2007. Bank concentration and fragility: impacts and mechanics, in M. Carey, R. Stulz (Eds.). The risks of financial institutions. Cambridge, MA: NBER, 193-231. http://dx.doi.org/10.7208/chicago/9780226092980.003.0006

Beck, T.; Demirgunc-Kunt, A.; Levine, R. 2012. Financial institutions and markets across countries and over time: data and analysis, World Bank Economic Review 24(1): 77-92.

http://dx.doi.org/10.1093/wber/lhp016

Berger, A. N.; Klapper, L. F.; Turk-Ariss, R. 2009. Bank competition and financial stability, Journal of Financial Services Research 35(2): 99-118. http://dx.doi.org/10.1007/s10693-008-0050-7

Blundell, R. W.; Bond, S. R. 1998. Initial conditions and moment restrictions in dynamic panel data models, Journal of Econometrics 87: 115-143.

http://dx.doi.org/10.1016/S0304-4076(98)00009-8

Body, J.; De Nicolo, G. 2005. The theory of bank risk taking revisited, Journal of Finance 60: 1329-1343. http://dx.doi.org/10.1111/j.1540-6261.2005.00763.x

Caminal, R.; Matutes, C. 2002. Market power and banking failures, International Journal of Industrial Organizations 20: 1341-1361. http://dx.doi.org/10.1016/S0167-7187(01)00092-3

Chang, E. J.; Guerra, S. M.; Lima, E. J. A.; Tabak, B. M. 2008. The stability-concentration relationship in the Brazilian banking system, International Financial Markets, Institutions and Money 18: 388-397. http://dx.doi.org/10.1016/j.intfin.2007.04.004

Claessens, S.; Laeven, L. 2004. What drives bank competition? Some international evidence, Journal of Money, Credit, and Banking 36(3): 563-583. http://dx.doi.org/10.1353/mcb.2004.0044

Cipollini, A.; Fiordelisi, F. 2009. The impact of bank concentration on financial distress: the case of the European banking system, Working Paper No. 09021. Centro Studi di Banca e Finanza.

Deltuvaite, V. 2010. The concentration-stability relationship in the banking system: an empirical research, Ekonomika ir Vadyba 15: 900-909.

Demirguc-Kunt, A.; Detragiache, E. 1998. The determinants of banking crises in developing and developed countries, IMF Staff Papers 45(1): 81-109. http://dx.doi.org/10.2307/3867330

De Nicolo, G.; Batholomew, P.; Zaman, J.; Zephirin, M. 2003. Bank consolidation, conglomeration and internationalization: trends and implications for financial risk, IMF Working Paper No. 03/158.

Dickey, A. D.; Fuller, A. W. 1981. Likelihood ratio statistics for an autoregressive time series with a unit root, Econometrica 49: 1057-1072. http://dx.doi.org/10.2307/1912517

Festic, M; Beko, J. 2008. The banking sector and macroeconomic performance in Central and Eastern Europe, Czech Journal of Economics and Finance 58(3/4): 131-151.

Festic, M; Kavkler, A. 2012. The roots of the banking crisis in the new eu member states: a panel regression approach, Romanian Journal of Economic Forecasting 15(1): $20-40$.

Festic, M; Kavkler, A.; Repina, S. 2011. The macroeconomic sources of systemic risk in the banking sectors of five new EU member states, Journal of Banking and Finance 35: 310-322. http://dx.doi.org/10.1016/j.jbankfin.2010.08.007

Foos, D.; Norden, L.; Weber, M. 2010. Loan growth and riskiness of banks, Journal of Banking and Finance 34: 2929-2940. http://dx.doi.org/10.1016/j.jbankfin.2010.06.007

Hausman, J. A. 1978. Specification tests in econometrics, Econometrica 46(6): 1251-1271. http://dx.doi.org/10.2307/1913827

Hausman, J. A.; Taylor, W. 1981. Panel data and unobservable individual effects, Econometrica 49: 1377-1399. http://dx.doi.org/10.2307/1911406 
Hellman, T.; Murdock, K.; Stiglitz, J. E. 2000. Liberalization, moral hazard in banking, and prudential regulation: are capital requirements enough?, American Economic Review 90(1): 147-165. http://dx.doi.org/10.1257/aer.90.1.147

Im, K. S.; Pesaran, M. H.; Shin, Y. 2003. Testing for unit roots in heterogeneous panels, Journal of Econometrics 115: 53-74. http://dx.doi.org/10.1016/S0304-4076(03)00092-7

Jakubik, P. 2007. Macroeconomic environmental and credit risk, Czech Journal of Economics and Finance 57(1/2): 60-78.

Jimenez, G.; Lopez, J. A.; Saurina, J. 2007. How does competition impact bank risk taking?, Federal Reserve Bank of San Francisco Working Paper No 2007-23.

Keeton, W.; Morris, C. S. 1987. Why do banks' loan losses differ?, Federal Reserve Bank of Kansas City, Economic Review May: 3-21.

Klomp, J.; Haan, J. De. 2012. Banking risk and regulation: does one size fit all?, Journal of Banking and Finance 36(12): 3197-3212. http://dx.doi.org/10.1016/j.jbankfin.2011.10.006

Laeven, L.; Valencia, F. 2010. Resolution of banking crises: the good, the bad, and the ugly, IMF Working Paper No. 10/146.

Levin, A.; Lin, C. F.; Chu, C. J. 2002. Unit root tests in panel data: asymptotic and finite sample properties, Journal of Econometrics 108: 1-24. http://dx.doi.org/10.1016/S0304-4076(01)00098-7

Louzis, D. P.; Vouldis, A. T.; Metaxas, V. L. 2012. Macroeconomic and bank-specific determinants of non-performing loans in Greece: a comparative study of mortgage, business and consumer loan portfolios, Journal of Banking and Finance 36: 1012-1027.

http://dx.doi.org/10.1016/j.jbankfin.2011.10.012

Matutes, C.; Vives, X. 2000. Imperfect competition, risk taking, and regulation in banking, European Economic Review 44: 1-34. http://dx.doi.org/10.1016/S0014-2921(98)00057-9

Nkusu, M. 2011. Nonperforming loans and microfinancial vulnerabilities in advanced economies, IMF Working Paper No. 11/161.

Panzar, J. C.; Rosse, J. N. 1987. Testing for monopoly equilibrium, Journal of Industrial Economics 35: 443-456. http://dx.doi.org/10.2307/2098582

Phillips, P. C. B. İ; Perron, P. 1988. Testing for a unit root in time series regression, Biometrika 75: 335-346. http://dx.doi.org/10.1093/biomet/75.2.335

Pedroni, P. 1999. Critical values for cointegration tests in heterogeneous panels with multiple regression, Oxford Bulletin of Economics and Statistics 61: 653-670.

http://dx.doi.org/10.1111/1468-0084.61.s1.14

Pedroni, P. 2000. Fully modified OLS for heterogeneous cointegrated panels, Advances in Econometrics 15: 93-130. http://dx.doi.org/10.1016/S0731-9053(00)15004-2

Pedroni, P. 2001. Purchasing power parity tests in cointegrated panels, Review of Economics and Statistics 83(4): 727-731. http://dx.doi.org/10.1162/003465301753237803

Pedroni, P. 2004. And panel cointegration: asymptotic and finite sample properties of pooled time series tests with application to the PPP hypothesis: new results, Econometric Theory 20: 597-627. http://dx.doi.org/10.1017/S0266466604203073

Ruiz-Porras, A. 2008. Banking competition and financial fragility: evidence from panel-data, Estudios Económicos 23: 49-87.

Salas, V.; Saurina, J. 2002. Credit risk in two institutional regimes: Spanish commercial and saving banks, Journal of Financial Services Research 22(3): 203-224.

http://dx.doi.org/10.1023/A:1019781109676

Sargan, J. D. 1958. The estimation of economic relationships using instrumental variables, Econometrica 26(3): 393-415. http://dx.doi.org/10.2307/1907619 
Schaeck, K.; Cihak, M.; Wolfe, S. 2009. Are more competitive banking systems more stable?, Journal of Money, Credit and Banking 41: 711-734.

http://dx.doi.org/10.1111/j.1538-4616.2009.00228.x

Schaffer, M. 2008. XTIVREG2: Stata Module to Perform Extended IV/2SLS, GMM and AC/HAC, LIML and k-Class Regression for Panel Data Models. Boston: Boston College Department of Economics, Statistical Software Components Number S456501.

Sinkey, J. F.; Greenwalt, M. Ç. B. 1991. Loan-loss experience and risk-taking behavior at large commercial banks, Journal of Financial Services Research 5: 43-59.

http://dx.doi.org/10.1007/BF00127083

Atilla ÇIFTER is an Assistant Professor of Econometrics at Istanbul Kemerburgaz University and holds a PhD in Econometrics from Marmara University, Turkey. Dr. Cifter's researches are published in various international journals including Economic Modelling, Physica A: Statistical Mechanics and Applications, and Journal of Risk Finance. His research interests span macroeconomics, applied macroeconometrics, and time series analysis. 